\title{
The Effect of Digital Service Quality (BRIMO) on Customer Loyalty through Customer Trust and Satisfaction on COVID-19 Situation (Pt Bank Rakyat Indonesia Medan Regional Office)
}

\author{
Martin Siagian ${ }^{1}$, Endang Sulistya Rini' ${ }^{2}$, Syafrizal Helmi Situmorang ${ }^{3}$ \\ ${ }^{1,2,3}$ Department of Management, University of Sumatera Utara, Medan, Indonesia.
}

Corresponding Author: Martin Siagian

\begin{abstract}
Advances in information technology and the widespread use of the internet have changed the method of service delivery. Banks now provide their services through electronic banking (ebanking) channels. Personal computers and cell phones are media where customers can use ebanking services, with the terms "online banking", "internet banking" and "electronic banking" being used interchangeably. BRImo is the latest application from BRI Mobile that combines the functions of mobile banking, internet banking, and electronic money or Tbank into one application with a more complete and attractive transaction menu, only by using a cellphone they can make transactions without having to go to the BRI office to reduce mobility and the spread of the Covid-19 virus in a pandemic situation. In the period from 2018 to 2020, there was an increase in BRImo application users from 384,412 people to 827,759 . but not comparable to the large number of deposit customers of Bank BRI Medan Region, in 2020 only $14.43 \%$ of the 5,735,381 customers of Bank BRI Medan Region who use BRImo with an average transaction of 122 times per customer per year. Phenomenon which often happens to BRI Bank customers to the BRImo application, either directly or indirectly, such as the quality of digital services provided to customers who have not been satisfied by customers so that it has an impact on customers' decisions not to return to transactions using BRImo and the impact of these problems will decrease the number of transactions and a decrease in fee-based income in the online
\end{abstract}

banking digital service application sector. The purpose of this study was to analyze the effect of BRImo's digital service quality on customer loyalty through customer trust and satisfaction in the Covid-19 situation at PT. Bank Rakyat Indonesia (Persero) Tbk Medan Branch Office. The population of this study is customer savings deposits, not corporate customers (group accounts), with the criteria of a sample of customers who use the BRImo application more than once with a total sample of 400 respondents. The sampling method used is purposive sampling; data analysis is carried out through PLS-SEM using the SmartPLS 3.0 program. The results of the study indicate that the quality of BRImo's digital services directly has a positive and significant effect on customer loyalty through customer trust and satisfaction.

Keywords: BRImo Digital Service Quality, Customer Loyalty, Customer Trust, Customer Satisfaction

\section{INTRODUCTION}

The banking sector has an important role in reducing the impact of the Covid-19 pandemic that has spread in Indonesia since last February. Liquidity conditions had indeed become a concern for the banking industry at the beginning of the Covid-19 pandemic. However, currently the condition of the banking industry is relatively stable, although it is necessary to continue to increase vigilance in anticipating the negative impacts of Covid-19. The Indonesian government has responded to 
this condition in order to maintain the stability of the Indonesian financial system. This effort certainly requires the participation of all parties in helping the Government of Indonesia to get through this difficult time.

Bank BRI implemented several new regulations related to the impact of Covid19 in the banking world. For loans, customers are relieved by a restructuring program, namely by extending the loan repayment period, but only by paying interest on the loan. For deposits, Bank BRI encourages the opening of online accounts with barcodes through the BRImo application; Promote more BRI banking products to social media such as Instagram, Facebook and YouTube; free transfer fees between BRI banks and increase the withdrawal limit through private label ATMs from 5 million per day to 10 million per day and increase the transfer limit for fellow BRI banks from 20 million per day to 50 million per day (Bank BRI, 2020).

BRImo is the latest application from BRI Mobile that combines the functions of mobile banking, internet banking, and electronic money or Tbank into one application with a more complete and attractive transaction menu. Initially all these transactions could only be accessed through different applications, but now the three types of banking transactions have been combined into one application. The application that combines the three types of banking transactions is BRImo, which is the latest version of the digital banking application from BRI Mobile.

BRImo is a banking transaction service facility through the internet network that can be accessed 24 hours. BRImo will provide convenience for non-cash transactions to customers, practicality, security and convenience in conducting online transactions whenever and wherever customers are. The advantage of using the BRImo service is that it can save time, where customers don't need to leave their desks, they just use the application on a smartphone that is connected to the internet, so they can make transactions anytime, anywhere.

BRImo is a service provided to perform various banking transactions through sharing features available on smart phones (smartphones). To be able to access the m-banking service, customers need to download the application through the Play Store or Appstore. Basically, improving the quality of e-banking services is seen as the best strategic means to make customers loyal to the e-banking system (Brun et al., 2015). Shankar (2018) shows that if consumers receive quality interactive services through e-banking sites, they will reuse these platforms to take advantage of banking services and recommend others to use them. Focusing on e-banking loyalty is important for banks to maintain relationships with consumers and attract potential customers (Amin, 2016). Therefore, banks must develop marketing strategies to provide superior value to customers so that they are loyal to ebanking services (Kotler et al., 2016).

In this study, a survey was conducted on 30 respondents representing customers of the BRI Bank Regional Office which became the head office of BRI throughout North Sumatra, consisting of 24 branch offices and 270 work units located in the North Sumatra region, the results showed that $46.67 \%$ of respondents answered Yes for questions about customers who will not switch to another bank and still choose Bank BRI. As many as $83.33 \%$ of respondents answered Yes to statements related to recommending BRI Bank products to others. Consistent use of products, in this case banking products from Bank BRI answered Yes by $86.67 \%$ of respondents. During the Covid-19 pandemic, many customers were reluctant to go to the bank to carry out their banking activities for fear of the spread of the Covid19 virus. In this case, Bank BRI is aggressively promoting the BRImo digital banking application which will make it easier for customers to conduct banking transactions wherever and whenever they 
want. The phenomenon of problems regarding customer loyalty that occurs today is that a small number of customers use the BRImo application as a digital payment tool when conducting non-cash transactions and most of the customers only activate the BRImo application but do not use the BRImo application. One of the factors that influence the loyalty of Bank BRI customers is the quality of service. Bank BRI always strives to improve and maintain the quality of services provided to attract customers. Quality is seen as a tool to achieve competitive advantage, because quality is one of the main factors that determine the selection of products and services for customers. In addition to service quality, trust and satisfaction also affect customer loyalty. Trust is the foundation of a business. Building customer trust is one way to create and retain customers. In the banking industry, Tabrani (2017) defines that trust is associated with acceptance of vulnerability, risk, interdependence and involves confident expectations about future behavior. Trust is important for customerbank relationships and for customer relationships in general, for several reasons. Trust facilitates transactions with customers.

One of the benchmarks for the success of a bank depends on customer satisfaction. For this reason, related parties must build customer trust so that they always use the services or products that have been provided. The more customers have confidence in the bank, the more funds are collected and replayed so as to achieve optimal profitability. In situations with intense competition, customers often do not have loyalty to a bank because of the many offers given to customers, and customers will always choose the offer that is most profitable for them. In the banking industry, customer loyalty is one proof that the bank has been able to compete in providing excellent service to every customer.

\section{LITERATURE REVIEW e-Service Quality}

Service quality is formed from two concepts, service and quality. Kotler (2016) defines a service as any act or performance that one party can offer to another, which is essentially intangible, and does not result in the ownership of anything, and produces it with or without a physical product. Eservice quality is defined as the extent to which a website facilitates efficient and effective shopping, purchasing and delivery (Zeithaml et al, 2018). Chase in Harish (2017) defines the quality of electronic digital services as services provided to Internet network consumers as an extension of the ability of a site to facilitate shopping, purchasing and distribution activities effectively and efficiently. E-Service Quality is a combination of internet-based service quality consisting of efficiency, fulfillment, system availability, privacy. Where customers will feel more efficient in conducting transactions in terms of time and cost, as well as the availability of information and smooth transactions are the choice of customers to transact through the availability of adequate internet system and network facilities and guarantees for the confidentiality of customer data.

\section{Customer Trust}

Trust is a company's willingness to depend on business partners (Kotler, 2016). Trust may be based on knowledge and opinion. Trust is the level of consumer certainty when his thoughts are clarified by repeated recall of market participants and their friends. Trust can drive intent to buy or use a product by eliminating doubt.

Trust is the belief that a person will get what is expected of others. Trust concerns a person's willingness to behave in a certain way because of the belief that his partner will give him what he expects and an expectation that is generally owned by someone that the words, promises or statements of others can be trusted (Cahyani, 2018). 


\section{Customer Satisfaction}

According to Kotler (2016) customer satisfaction is the level of feeling where someone states the results of a comparison of the performance of the product or service received as expected. According to Tjiptono (2016) customer satisfaction is the buyer's cognitive situation regarding the equivalence or disproportion between the results obtained compared to the sacrifices made. Tjiptono (2016), formulates "Customer satisfaction as an overall attitude towards an item or service after its acquisition and use". In other words, customer satisfaction is a post-purchase evaluative assessment resulting from a specific selection.

\section{Customer Loyalty}

The notion of loyal consumers according to Griffin (2018) is "consumers who have characteristics, including making purchases or using products/services repeatedly at the same business entity, buying or using product lines and services offered by the same business entity, inform others about the satisfactions that customers get from the business entity and demonstrate immunity to offers from competing business entities. Furthermore, according to Ali (2016) "Customer loyalty is behavior related to a product, including the possibility of renewing the brand contract in the future, how likely is the customer to change their support for the brand, how much is the customer's desire to increase the positive image of a product". If the product is not able to satisfy the customer, the customer will react by exit (the customer states he has stopped buying the brand or product) and voice (the customer expresses direct dissatisfaction with the company). Meanwhile, according to Griffin (2018) "Customer loyalty is defined as people who buy, especially those who buy regularly and repeatedly". A customer is someone who continuously and repeatedly comes to the same place to satisfy his desire by having a product or getting a service and paying for the product or service.
In the context of e-banking, customer loyalty can be interpreted as "the tendency of consumers to frequently visit bank websites, regularly use e-banking services, and spread positive word of mouth about e-banking services" (Amin, 2016). In particular, loyal e-banking customers tend to spread positive word of mouth through electronic devices and social media pages, thereby giving a positive impression of ebanking to other customers. They will also prefer e-banking over other banking channels. Shows that if consumers receive quality interactive services through ebanking websites, they will reuse this platform to take advantage of banking services and recommend others to use them. focusing on e-banking loyalty is important for banks to maintain relationships with consumers and attract potential customers (Amin, 2016).

\section{MATERIALS \& METHODS}

The method used in this research is quantitative method research, where according to Malhotra et al., (2017), quantitative research is a research methodology that seeks to quantify data and usually applies certain statistical analysis. This research was conducted at 6 branch offices of BRI Regional Office in Medan, namely BRI Kanca Gatot Subroto, Putri Hijau, Medan Thamrin, SM Raja, Tebing Tinggi and Tanjung Balai, which are part of BRI Medan Regional Office located at Jalan Putri Hijau No. 2a, Medan. In this study, the population of customers who use BRImo is 827,759 people who are not corporate customers (groups) in all regional offices of Bank BRI North Sumatra. The technique or sampling used in this research is purposive sampling. Determination of the number of samples in this study using the Slovin formula with the following calculations:

$$
n=\frac{N}{1+N(e)^{2}}
$$

By using the above formula, the number of research samples can be calculated as follows: 


$$
\begin{aligned}
& \boldsymbol{n}=\frac{827.759}{1+827.759(0.05)^{2}} \\
& \boldsymbol{n}=399.98 \text { rounded to } 400 \text {. }
\end{aligned}
$$

\section{Statistical Analysis \\ RESULT \\ Respondent's Descriptive}

Based on the results of the analysis of the characteristics of the respondents, it is known that respondents with the age of $26>$ 40 years are included in the productive age for customers to carry out banking transactions using the BRImo application, then respondents with female gender are more dominant than male respondents in this study based on domicile area. it is known that the characteristics of the most respondents are the customers of the Medan Putri Hijau, SM Raja, Medan Thamrin and Tebing Tinggi branches with an average of 67 respondents $(16.75 \%)$, and the lowest respondents are the Medan Gatot Subroto and Tanjung Balai branches with an average of an average of 66 respondents (16.50\%). Based on the work, it is known that the respondent of the work of Private Employees is more dominant in using the BRImo application than other jobs and the types of transactions using BRImo are generally for transfer-type transactions.

\section{DISCUSSION}

\section{The Influence of BRImo's Digital} Service Quality on Customer Loyalty

Based on the results of hypothesis testing, it shows that the variable of BRImo's digital service quality has a positive and significant effect on customer loyalty. This is evidenced by the significance value for the variable BRImo digital service quality 0.000 with an alpha of $5 \%(\mathrm{p}=0.000<0.05)$, meaning that the quality of BRImo digital services has a significant effect on customer loyalty. This research is in line with research conducted by I Gede Yogi Pramana and $\mathrm{Ni}$ Made Rastini (2016), Amit Shankar (2018), Pinar zkan (2019), and Pramana (2016) which state that service quality has a positive and significant effect on customer loyalty. However, this is not in line with the research conducted by Putri (2017) which states that Service Quality has no significant effect on loyalty to Dian Comp Ambarawa customers.

\section{The Influence of BRImo's Digital Service Quality on Customer Trust}

Based on the results of hypothesis testing, it shows that the variable of BRImo's digital service quality has a positive and significant effect on customer trust. This is evidenced by the significance value for the BRImo digital service quality variable of 0.000 with an alpha of $5 \%(\mathrm{p}=$ $0.000<0.05$ ), meaning that the quality of BRImo digital service has a significant effect on customer trust. This research is in line with research conducted by I Gede Yogi Pramana and Ni Made Rastini (2016), Molden Elrado H, Srikandi Kumadji, Edy, Yulianto (2015), Nurhadi \& Asriel (2018), Bintang Ichtianto R (2017) and Ramadhanta Surya Artana (2016) which states that service quality has a positive and significant effect on customer trust.

\section{The Influence of BRImo's Digital Service Quality on Customer Satisfaction}

Based on the results of hypothesis testing, it shows that the variable of BRImo's digital service quality has a positive and significant effect on customer satisfaction. This is evidenced by the significance value for the variable BRImo digital service quality 0.000 with an alpha of $5 \%(\mathrm{p}=0.000<0.05)$, meaning that the quality of BRImo digital services has a significant effect on customer satisfaction. This means that if the quality of BRImo's digital services is improved, it will increase customer satisfaction. PT. Bank Rakyat Indonesia as a service company, of course, makes service to customers a vital and basic thing so that every customer who transacts on the BRImo application gets satisfaction. This research is in line with research conducted by Molden Elrado H, Srikandi Kumadji, Edy Yulianto (2015), Lintang Ayu 
Setyani (2014), Bintang Ichtianto R (2017), and Pinar zkan (2019) stating that service quality has a positive and significant effect on customer satisfaction. customer.

\section{The Influence of Customer Trust on Customer Loyalty}

Based on the results of hypothesis testing, it shows that the variable of customer trust has a positive and significant effect on customer loyalty. This is evidenced by the significance value for the customer trust variable of 0.000 with an alpha of $5 \%$, namely ( $\mathrm{p}=0.000<0.05)$, meaning that customer trust has a significant effect on customer loyalty. This means good customer trust. This is in line with research conducted by I Gede Yogi Pramana and Ni Made Rastini (2016), Molden Elrado H, Srikandi Kumadji, Edy, Yulianto (2015), Molden Elrado H, Srikandi Kumadji, Edy, Yulianto ( 2015), Nurhadi \& Asriel (2018), and Pauline WJ Van Esterik-Plasmeijer (2016) which states that customer trust has a positive and significant effect on customer loyalty.

\section{The Effect of Customer Satisfaction on Customer Loyalty}

Based on the results of hypothesis testing, it shows that the customer satisfaction variable has a positive and significant effect on customer loyalty. This is evidenced by the significance value for the customer satisfaction variable of 0.000 with an alpha of $5 \%$, namely $(\mathrm{p}=0.000$ $<0.05$ ), meaning that customer satisfaction has a significant effect on customer loyalty. The more satisfied customers are with the BRImo application, it will increase customer loyalty to the use of the BRImo application so that customers become loyal to continue using the banking application of PT. Bank Rakyat Indonesia (Persero) Tbk, namely BRImo. This is in line with research conducted by Molden Elrado H, Srikandi Kumadji, Edy, Yulianto (2015), Lintang Ayu Setyani (2014), Ramadhanta Surya Artana (2016) and Rina Purnama (2019) which states that customer satisfaction has a positive and significant effect on customer loyalty.

\section{The Influence of BRImo's Digital Service Quality on Customer Loyalty Through Customer Trust}

Based on the hypothesis test, it is known that the quality of BRImo's digital service has a positive and significant effect on the customer loyalty variable through customer trust. This is proven based on the significance value, which is 0.000 with an alpha of $5 \%(p=0.000<0.05)$, meaning that the quality of BRImo's digital services has a significant effect on customer loyalty through customer trust. When customers believe in the service quality of the BRImo application, they will be loyal and use the BRImo application continuously in their daily transaction activities wherever and whenever they want. This research is in line with research conducted by Pinar zkan et al (2019), Charles Makanyeza (2017), Adji Achmad Rinaldo Fernandes et al (2017) and Sigit and Soliha (2017) which showed that the quality of BRImo digital services had a positive and negative effect on significant impact on customer loyalty through customer trust.

\section{The Influence of BRImo's Digital Service Quality on Customer Loyalty through Customer Satisfaction}

Based on the hypothesis test, it is known that the quality of BRImo's digital service has a positive and significant effect on the customer loyalty variable through customer satisfaction. This is evidenced by the significance value of 0.000 with an alpha of $5 \%(p=0.000<0.05)$, meaning that the quality of BRImo's digital services has a significant effect on customer loyalty through customer satisfaction. When customers are satisfied with the quality of service on the BRImo application, they will be loyal and use the BRImo application continuously in their daily transaction activities. This research is in line with research conducted by Azka AL Afifah (2017), Ramadhanta Surya Artana (2016), 
Sigit and Soliha (2017) and Cahyani, Gede Bayu Rahanatha (2015) which show that the quality of BRImo digital services has a positive and significant effect on customer loyalty through customer trust.

\section{CONCLUSION}

1. BRImo's Digital Service Quality has a positive and significant impact on Customer Loyalty to customers of PT Bank Rakyat Indonesia (Persero) Tbk Medan Regional Office.

2. BRImo's Digital Service Quality has a positive and significant impact on Customer Trust in PT Bank Rakyat Indonesia (Persero) Tbk's Medan Regional Office customers.

3. BRImo's Digital Service Quality has a positive and significant impact on customer satisfaction for customers of PT Bank Rakyat Indonesia (Persero) Tbk Medan Regional Office.

4. Customer Trust has a positive and significant impact on Customer Loyalty to customers of PT Bank Rakyat Indonesia (Persero) Tbk Medan Regional Office.

5. Customer Satisfaction has a positive and significant effect on Customer Loyalty to customers of PT Bank Rakyat Indonesia (Persero) Tbk Medan Regional Office.

6. BRImo's Digital Service Quality has a positive and significant impact on customer loyalty through customer trust in the customers of PT Bank Rakyat Indonesia (Persero) Tbk Medan Regional Office.

7. BRImo's Digital Service Quality has a positive and significant impact on customer loyalty through customer satisfaction on customers of PT Bank Rakyat Indonesia (Persero) Tbk Medan Regional Office.

\section{Acknowledgement: None}

\section{Conflict of Interest: None}

Source of Funding: None

\section{REFERENCES}

1. Adrian Payne, Services Marketing Pemasaran Jasa, Yogyakarta: Andi Yogyakarta.

2. Afifah, Azka Al (2016). pengaruh kualitas layanan, kepercayaan, dan kepuasan terhadap loyalitas pelanggan nasabah (studi kasus di PT bank Syariah mandiri kantor cabang Simpang Patal Palembang)

3. Ali, Hasan. 2016. Marketing dan KasusKasus Pilihan. Buku I, Cetakan ke-dua. Penerbit: CAPS, Yogyakarta.

4. Amin, dkk. 2016. Pengaruh Kualitas Pelayanan Terhadap Kepuasan Pelanggan dan Dampkanya Pada Loyalitas Pelanggan. Jurnal Administrasi Bisnis, Vol.17 No 1 Desember 2015.

5. Amin, Muslim. 2015. Internet Banking Service Quality and its Implication on Customer Satisfaction and E-Customer Loyalty. International Journal of Bank Marketing Vol. 34 No. 3, 2016 pp. 280-306.

6. Brun, Isabelle. 2013. E-Relationship Marketing: a Cognitive Mapping Introspection in the Banking Sector. European Journal of Marketing Vol. 48 No. 3/4, 2014 pp. 572-594.

7. Cahyani, Riananda Regita, 2018. Efektifitas Kognitif Behavior Therapy untuk menurunkan tingkat body shaming. Universitas Islam Negeri Maulana Malik Ibrahim, Malang.

8. Chase, Richard B., Jacobs, Robert F., Aquilano, Nicholas J., Operation Management for Competitive Advantage, 11th edition, McGraw-Hill Companies, inc., New York, 2007

9. Dharma, Robby, 2017. Pengaruh Kualitas Pelayanan, Kepercayaan, Dan Kepuasan Terhadap Loyalitas Pelanggan Pada PT Padang Tour Wisata Pulau Padang. Jurnal EKOBISTEK Fakultas Ekonomi, Vol. 6, No. 2, Oktober 2017, Hal 349-359 ISSN: 2301-5268 | E-ISSN: 2527-9483

10. Elrado, Molden et. al. 2015. Pengaruh Kualitas Pelayanan Terhadap Kepuasan, Kepercayaan Dan Loyalitas (Survei pada Pelanggan yang Menginap di Jambuluwuk Batu Resort Kota Batu) Jurnal Administrasi Bisnis (JAB)|Vol.15 No. 2 Oktober.

11. Erwin, 2017. Kontribusi Kualitas Jasa, Kepercayaan Dan Kepuasan Konsumen Dalam Menciptakan Loyalitas Konsumen. 
Jurnal Manajemen Vol.13(2) : 85-191. Th. 2017 ISSN: 1907-0896

12. Esterik-Plasmeijer, Pauline W.J. van, and W. Fred van Raaij. (2017). Banking System Trust, Bank Trust, and Bank Loyalty. International Journal of Bank

Marketing, 97-111.

13. Griffin, Jill. 2010. Customer Loyalty, Menumbuhkan dan Mempertahankan Kesetiaan Pelanggan. Alih Bahasa Dwi Kartini Yahya. Jakarta: Erlangga.

14. Harish, Irfan Nurahmadi, 2017. Pengaruh Kepercayaan Nasabah dan Kualitas Pelayanan Terhadap Kepuasan Nasabah. Universitas Islam Negeri, Syarif Hidayatullah, Jakarta.

15. Kasmir. (2017). Analisis Laporan Keuangan. Jakarta: PT Rajagrafindo Persada.

16. Kotler, Phillip dan Kevin Lane Keller. (2016). Manajemen Pemasaran edisi 12 Jilid 1 \& 2. Jakarta: PT. Indeks.

17. Lapasiang, Denis, Silcyljeova Moniharapon, Sjendry Loindong, 2017. Pengaruh Kepercayaan Dan Komitmen Terhadap Loyalitas Nasabah Pada PT. Pegadaian (Persero) Cabang Karombasan Manado. ISSN 2303-1174 Jurnal EMBA Vol.5 No.3 September 2017

18. Lovelock, Christopher., Patterson, P. dan Wirtz, J. 2016. Services Marketing: An Asia-Pasific and Australian Perspective, Sixth Edition, Pearson, Australia.

19. Lupiyoadi, R., \& Hamdani. (2015). Manajemen Pemasaran Jasa. Jakarta: Salemba Empat.

20. Makanyeza, C,. \& Chikazhe, L. 2017. Mediators of the relationship between service quality and customer loyalty. International Journal of Bank Marketing, 35(3), 540-556. doi:10.1108/ijbm-11-2016-0164.

21. Malhotra, Naresh. K., D.F. Birks, and P. Wills. 2017. Marketing research: An Applied Approach. 5th ed. London: Pearson Education.

22. Markonah. 2017. Analisis Pengaruh Mobile Banking Terhadap Kepuasan dan Loyalitas Nasabah Bank Mandiri Cabang Jakarta. Prosiding Seminar Nasional Ekonomi dan Bisnis (hal 477). Malang: FEB Unikama.

23. Nurhadi \& Asriel. 2018. Pengaruh Kualitas Pelayanan Terhadap Kepercayaan Dan Kesetiaan Konsumen. Jurnal Economia, Volume 14, Nomor1, April 2018
24. Oliver S. 2015. Public involvement in research: making sense of the diversity. Journal of health services research \& policy20.1: 45-51.

25. Olivia Mimin Trisnawati dan Syaifuddin Fahmi. 2017. Pengaruh Kualitas Layanan Elektronik (E-Servqual) Terhadap Kepuasan Nasabah Pengguna Mobile Banking (Studi Pada Pengguna Mobile Banking Bank Sinarmas Cabang Malang). Jurnal Manajemen Bisnis Indonesia Vol. 4, No. 2, Feb 2017

26. Pramana, I Gede Yogi dan Ni Made Rastini, 2016. Pengaruh Kualitas Pelayanan Terhadap Kepercayaan Nasabah Dan Loyalitas Nasabah Bank Mandiri Cabang Veteran Denpasar Bali. E-Jurnal Manajemen. Public Knowledge Project.

27. Priansa, Donni Juni. 2017. Perilaku Konsumen: Dalam Persaingan Bisnis Kontemporer. Bandung: Alfabeta.

28. Putri, Yulia Larasati, 2017. Pengaruh Kualitas Pelayanan Terhadap Loyalitas Pelanggan Dengan Kepuasan Sebagai Variabel Intervening (Studi Persepsi Pada Pelanggan Dian Comp Ambarawa). Among Makarti Vol.10 No.19, Juli 2017

29. Shaikh, A. and Karjaluoto, H. (2015) Mobile Banking Adoption: A Literature Review. Telematics and Informatics, 32, 129-142.

30. Shankar, A., \& Datta, B. (2018). Factors affecting mobile payment adoption intention: An Indian perspective. Global Business Review, 19(3_suppl), S72-S89.

31. Sinulingga, Sukaria. (2016). Metode Penelitian. Medan: USU Press.

32. Tabrani, Rusyan, dkk, Pendekatan dalam Proses Belajar Mengajar, (Bandung: Remaja Karya)

33. Thungasal, Chandra Eddy dan Hotlan Siagian, 2019. Pengaruh Kualitas Layanan Dan Harga Terhadap Loyalitas Pelanggan Melalui Kepuasan Pelanggan Pada Hotel Kasuari. AGORA Vol. 7, No. 1

34. Tjiptono Fandy dan Gregorius chandra. 2016. Service, Quality \& satisfaction. Yogyakarta. Andi.

35. Trisya dan Teofilus. 2016. Pengarus Dimensi Kualitas Layanan Elektronik terhadap Nilai Jasa yang Diterima dan Kepuasan Konsumen (Studi Empiris: Aplikasi GO-JEK). Jurnal Entrepreneur dan Entrepreneurship 
Martin Siagian et.al. The effect of digital service quality (BRIMO) on customer loyalty through customer trust and satisfaction on COVID-19 situation (Pt Bank Rakyat Indonesia Medan Regional Office).

36. Yusuf Rombe. 2020. Stategi Meningkatkan Kualitas Layanan Melalui Digitalisasi Jasa Perbankan Di PT. Bank Negara Indonesia (Persero) Tbk. Kantor Jakarta Pusat. Jurnal dikti9.id/Ekonomika Vol 4. No 2. Oktober 2020

37. Zeithaml, Valarie A and Bitner. (2016). Service Marketing 2nd edition: Integrating Customer Focus. New York.McGraw-Hill Inc.

38. Zaizafun Husnita dan Maya Ariyanti. 2019. Pengaruh Kualitas Layanan Mobile Banking Terhadap Kepuasan Nasabah Bank Negara
Indonesia (Studi Kasus Mahasiswa/I

Bandung Raya). e-Proceeding of

Manajement. Vol. 6, No. 2, Agustus 2019

How to cite this article: Siagian M, Rini ES, Situmorang SH. The effect of digital service quality (BRIMO) on customer loyalty through customer trust and satisfaction on COVID-19 situation (Pt Bank Rakyat Indonesia Medan Regional Office). International Journal of Research and Review. 2021; 8(8): 263-271. DOI: https://doi.org/10.52403/ijrr.20210836 